\title{
Simulasi Penurunan Kadar Asam Askorbat Buah Jambu Biji (Psidium Guajava L.) Selama Penyimpanan Menggunakan Visual Basic 6.0
}

\author{
Annisa Azzahra ${ }^{1}$ Ratna $^{2 *}$, Agus Arip Munawar ${ }^{3}$ \\ ${ }^{1,2,3}$ Program Studi Teknik Pertanian, Fakultas Pertanian, Universitas Syiah Kuala, Banda Aceh \\ *Koresponden email: ratna@unsyiah.ac.id
}

Diterima: 7 April 2021

Disetujui: 10 Mei 2021

\begin{abstract}
Technological advances continue to develop rapidly and people need technology that is more efficient and faster in their work, including in the field of agriculture. Therefore, simulation is a suitable way to be implemented in the scope of modern society. This study aims to reduce the number of research and experimental trials in the laboratory because it takes a lot of time and money. This research refers to a simulation of decreasing levels of ascorbic acid in guava fruit during the storage period which is carried out by presenting data obtained from various sources, programming and simulation design using Visual Basic 6.0 and program testing. Guava fruit (Psidium guajava L) has vitamin C content about $183.5 \mathrm{mg} /$ 100 grams of material. The test results of this program, within 10 days of storage at room temperature $\left(25^{\circ} \mathrm{C}\right)$ the levels of Ascorbic Acid in Guava fruit decreased by $56.1 \%$ and decreased levels of Ascorbic Acid by $92.26 \%$, from $183.5 \mathrm{mg} / 100$ gr to around $12,84 \mathrm{mg} / 100 \mathrm{gr}$ guava fruit for 720 hours. Therefore, the results of this simulation program succeeded in approaching the real number of decreases in ascorbic acid levels tested in original observations.
\end{abstract}

Keywords: Ascorbic Acid, Guava,Computer Program, simulation, Visual Basic 6.0

\begin{abstract}
Abstrak
Saat ini kemajuan teknologi terus berkembang pesat dan teknologi yang lebih efisien serta cepat dalam menangani pekerjaan termasuk dalam bidang pertanian. Simulasi adalah salah satu cara yang cocok untuk diimplementasikan di lingkup masyarakat modern. Penelitian ini bertujuan untuk mengurangi jumlah penelitian dan eksperimen uji coba di laboratorium karena memakan waktu dan biaya yang besar. Penelitian ini mengacu pada simulasi penurunan kadar Asam Askorbat pada buah Jambu Biji selama masa penyimpanan dengan menggunakan Software Visual Basic 6.0 yang dilakukan dengan metode penyajian data dari berbagai sumber seperti jurnal-jurnal dan buku yang terkait, pembuatan program dan perancangan simulasi menggunakan Visual Basic 6.0 serta pengujian program. Buah Jambu Biji (Psidium guajava $L$ ) mempunyai kandungan vitamin $\mathrm{C}$ sekitar 183,5 mg/100 gram bahan. Hasil uji program ini, dalam 10 hari penyimpanan pada suhu kamar $\left(25^{\circ} \mathrm{C}\right)$ kadar Asam Askorbat buah Jambu Biji mengalami penurunan sebesar 56,1\% dan terjadi penurunan kadar Asam Askorbat sebesar 92,26\% yaitu dari 183,5 $\mathrm{mg} / 100$ gr menjadi sekitar 12, $84 \mathrm{mg} / 100$ gr buah Jambu Biji selama 720 jam atau 1 bulan. Hasil dari program simulasi ini berhasil mendekati angka real penurunan kadar asam askorbat yang diuji pada penelitian lapangan.
\end{abstract}

Kata Kunci: Asam Askorbat, Jambu Biji, program komputer, simulasi, Visual Basic 6.0

\section{Pendahuluan}

Saat ini kemajuan dunia di bidang teknologi terus berkembang sangat pesat. Kemajuan teknologi yang telah memasuki era 4.0 membuat perubahan besar pada kualitas hidup umat manusia seperti teknologi kecerdasan buatan dalam berbagai bidang. Implementasi berbagai teknologi baru yang sangat memungkinkan untuk dapat menciptakan obyek-obyek teknik yang dapat membantu dan mempermudah manusia dalam pengerjaan sesuatu lebih efisien dan cepat. Tak dapat dipungkiri kemajuan Teknologi di bidang pertanian pun perlu dikembangkan untuk membantu dan mempermudah para petani dan masyarakat dalam melakukan pekerjaannya.

Komoditas pertanian yang pertumbuhannya sangat banyak dan dan sering kita jumpai di Indonesia yaitu buah Jambu Biji. Buah yang umumnya tumbuh di daerah tropis termasuk di Indonesia dan juga buah yang banyak diminati oleh masyarakat. Banyaknya pedagang buah Jambu Biji yang dijumpai menunjukkan bahwa banyak konsumen yang sangat menyukai buah tersebut. Jambu Biji merupakan 
salah satu komoditas pertanian yang mengandung vitamin C tinggi yaitu sekitar $11-1160 \mathrm{mg} / 100$ gram terdapat pada jambu biji yang mempunyai rasa yang sangat menyenangkan..

Penelitian ini mengacu pada simulasi penurunan kadar Asam Askorbat pada buah Jambu Biji selama masa penyimpanan dengan menggunakan Software Visual Basic 6.0. Simulasi ini akan memberikan gambaran mengenai fenomena terjadinya penurunan kadar Asam Askorbat pada buah jambu biji setelah penyimpanan beberapa waktu tertentu. Melalui simulasi, maka jumlah penelitian dan eksperimen uji coba di laboratorium yang memakan waktu dan biaya dapat dikurangi [14]. Manfaat dari penelitian ini adalah untuk memberikan informasi dan pengetahuan terkait proses membangun simulasi penurunan kadar vitamin C pada buah Jambu Biji (Psidium guajava L.) selama masa penyimpanan dengan menggunakan Visual Basic 6.0.

\section{Metode Penelitian}

Penelitian ini dilaksanakan di Laboratorium Instrumentasi dan Energi, Program Studi Teknik Pertanian, Fakultas Pertanian, Universitas Syiah Kuala, Darussalam, Banda Aceh. Penelitian ini di laksanakan pada bulan September sampai Desember tahun 2020. Alat yang digunakan adalah laptop, aplikasi Microsoft Visual Basic 6.0. Bahan yang digunakan pada penelitian ini adalah data dan informasi mengenai kandungan asam askorbat pada buah Jambu Biji, jurnal-jurnal penelitian mengenai buah Jambu Biji dan beberapa buku tentang penggunaan software Visual Basic.

\section{Penyajian Data Buah Jambu Biji}

Data yang diperoleh bersumber dari buku, jurnal, artikel yang berkaitan dengan penelitian ini serta nilai-nilai dugaan yang disesuaikan dengan karakteristik sistem real. Berikut adalah data masukan (input data) yang diperlukan dalam penelitian ini yaitu :

1. Persen awal kadar asam askorbat (vitamin C) buah Jambu Biji (\%)

2. Luas permukaan kemasan polyethilene $(\mathrm{cm} 2)$

3. Tebal kemasan $(\mathrm{cm})$

4. Suhu penyimpanan $\left(25^{\circ} \mathrm{C}\right)$

5. Aktivitas kadar air awal buah Jambu Biji

6. Energi aktivasi

7. Berat bahan padatan $(\mathrm{g})$

8. Koefisien permeabilitas kemasan $(\mathrm{g} \mathrm{H} 2 \mathrm{o} \mathrm{cm}) / \mathrm{m} 2$ hari $\mathrm{mmHg})$.

\section{Pembuatan Program dan Perancangan Simulasi}

Nilai simulasi pada program yang akan dibangun didasarkan pada teori kinetika reaksi bahan pangan yang meliputi teori water activity, orde reaksi, lingkungan dan teori Arrhenius. Dalam proses pengolahan pangan, biasanya reaksi terjadi secara berantai. Pendekatan dasar untuk menentukan orde laju reaksi, dapat digunakan persamaan (i):

$$
-\frac{d C}{d t}=k C^{n}
$$

atau;

$$
\ln \left(-\frac{d C}{d t}\right)=\ln k+n \ln C
$$

C merupakan konsentrasi bahan, $k$ adalah konstanta laju reaksi, $n$ adalah orde reaksi dan $t$ merupakan waktu. Berdasarkan pendekatan persamaan ini, garis plot $\ln (-\mathrm{dC} / \mathrm{dt})$ dan $\ln \mathrm{C}$ akan memberikan garis lurus dimana slope nya menunjukan orde reaksi (n), seperti terlihat di Gambar 1. 

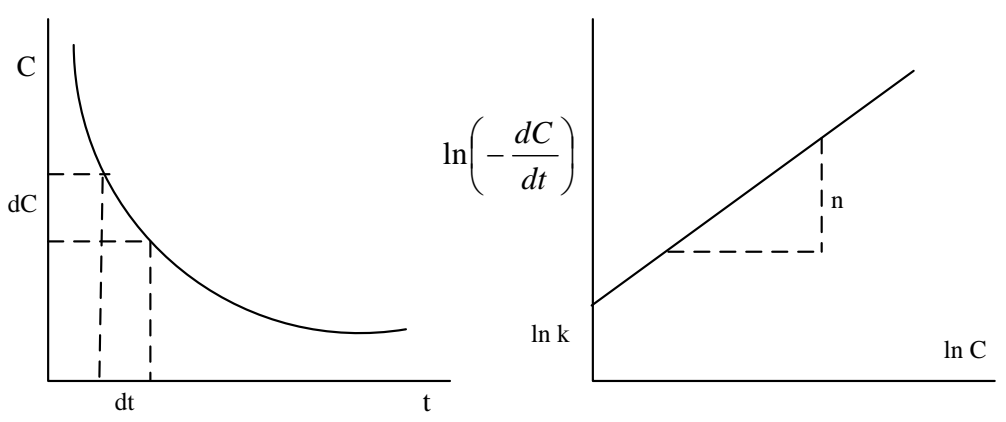

Gambar 1. Perubahan konsentrasi bahan pangan selama penyimpanan

Grafik perubahan Gambar 1 mengikuti model persamaan Arrhenius dimana konsentrasi bahan berubah secara proporsional terhadap waktu mengikuti bentuk eksponensial.

\section{Menentukan Aktivitas air}

Dalam penurunan suatu bahan pangan, berlaku persamaan BET (Bruneuer-Emmet-Teller) untuk menentukan aktivitas air $\left(\mathrm{a}_{\mathrm{w}}\right)$ sebagai berikut;

$$
\frac{a_{w}^{i}}{M\left(1-a_{w}^{i}\right)}=\frac{1}{W_{m} C}+\frac{(c-1) a_{w}^{i}}{W_{m} C}
$$

Jika dikalikan masing-masing ruas dengan $M\left(1-a_{w}^{i}\right)\left(W_{m} C\right)$, maka;

$$
\begin{aligned}
& \mathrm{W}_{\mathrm{m}} \mathrm{ca}^{\mathrm{i}}{ }_{w}=M\left(1-\mathrm{a}^{\mathrm{i}}{ }_{w}\right)+M\left(1-\mathrm{a}^{\mathrm{i}}{ }_{w}\right)(c-1) \mathrm{a}^{\mathrm{i}}{ }_{w} \\
& \mathrm{~W}_{\mathrm{m}} \mathrm{ca}^{\mathrm{i}}{ }_{w}=M\left(1-\mathrm{a}^{\mathrm{i}}{ }_{w}\right)+\left(M-M \mathrm{a}^{\mathrm{i}}{ }_{w}\right)(c-1) \mathrm{a}^{\mathrm{i}}{ }_{w} \\
& \mathrm{~W}_{\mathrm{m}} \mathrm{ca}^{\mathrm{i}}{ }_{w}=M-M \mathrm{a}^{\mathrm{i}}{ }_{w}+\left(M-M \mathrm{a}^{\mathrm{i}}{ }_{w}\right)\left(c \mathrm{a}^{\mathrm{i}}{ }_{w}-\mathrm{a}^{\mathrm{i}}{ }_{w}\right) \\
& \mathrm{W}_{\mathrm{m}} \mathrm{ca}^{\mathrm{i}}{ }_{w}=M-M \mathrm{a}^{\mathrm{i}}{ }_{w}+M c \mathrm{a}^{\mathrm{i}}{ }_{w}-M \mathrm{a}^{\mathrm{i}}{ }_{w}-M c\left(\mathrm{a}^{\mathrm{i}}{ }_{w}\right)^{2}+M\left(\mathrm{a}^{\mathrm{i}}{ }_{w}\right)^{2} . \\
& (M-M c)\left(\mathrm{a}^{\mathrm{i}}{ }_{w}\right)^{2}+\left(M c-W_{m} c-2 M\right) \mathrm{a}^{\mathrm{i}}{ }_{w}+M=0
\end{aligned}
$$

Sehingga, dengan rumus akar kuadrat, didapat:

$$
\left(\mathrm{a}^{\mathrm{i}}{ }_{w}\right)_{1}=\frac{-\left(M c-2 M-W_{m} c\right)+\sqrt{\left(M c-2 M-W_{m} c\right)^{2}-(4(M-M c) M)}}{2(M-M c)} .
$$

dan,

$$
\left(\mathrm{a}^{\mathrm{i}}{ }_{w}\right)_{2}=\frac{-\left(M c-2 M-W_{m} c\right)-\sqrt{\left(M c-2 M-W_{m} c\right)^{2}-(4(M-M c) M)}}{2(M-M c)}
$$

dimana:

$$
\begin{array}{ll}
\mathrm{M} & : \text { kadar air bahan }(\%) \\
a_{w}^{i} & : \text { aktivitas air } \\
\mathrm{c} & : \text { energi aktivasi } \\
\mathrm{T} & : \text { suhu penyimpanan }\left({ }^{\circ} \mathrm{C}\right)
\end{array}
$$

\section{Menentukan Perubahan Kadar Air Produk}

Perubahan kadar air produk bahan pangan dapat diduga dengan menggunakan model matematik sebagai berikut;

$$
\begin{aligned}
& \frac{d M}{d t}=P_{a b s} \frac{k}{x} \frac{A}{w_{s}}\left(\mathrm{a}^{\mathrm{o}}{ }_{w}-\mathrm{a}^{\mathrm{i}}{ }_{w}\right) \\
& \text { dan, } \\
& M_{n}=M_{n-1}+d M
\end{aligned}
$$


dimana:

$$
\begin{array}{ll}
\mathrm{M} & : \text { kadar air bahan }(\%) \\
\mathrm{P}_{\text {abs }} & : \text { tekanan absolut }(\mathrm{Pa}) \\
\mathrm{W}_{\mathrm{s}} & : \text { berat bahan padatan }(\mathrm{g}) \\
\mathrm{Wm} & : \text { Berat Bahan }(\mathrm{g}) \\
x & : \text { tebal kemasan }(\mathrm{m}) \\
d t & : \text { perubahan waktu (hari) } \\
a_{w}^{i} & : \text { aktivitas air }
\end{array}
$$

\section{Menentukan konstanta orde reaksi}

Konstanta orde reaksi dapat dicari dengan menggunakan persamaan;

$$
k=A_{1}+A_{2} a_{w}^{i}
$$

dimana:

A : luas permukaan bahan kemasan $\left(\mathrm{m}^{2}\right)$

$\mathrm{A}_{1} \quad$ : Konstanta numerik

$\mathrm{A}_{2} \quad$ : Konstanta Numerik

$k \quad:$ konstanta orde reaksi

$\mathrm{K}$ : Koefisien permeabilitas bahan kemasaan $\left(\mathrm{g} \mathrm{H}_{2} \mathrm{O} \mathrm{cm}\right) /\left(\mathrm{m}^{2}\right.$ hari $\left.\mathrm{mmHg}\right)$

4. Perubahan konsentrasi vitamin $\mathrm{C}$ adalah;

$$
C_{n}=C_{n-1} e^{-k_{n} d t}
$$

dimana:

$C_{n} \quad$ : konsentrasi kandungan bahan (Asam Askorbat) hari ke- $n(\%)$

\section{Pengujian Program}

Adapun pengujian terhadap program dilakukan dengan memasukkan berbagai macam tipe kombinasi data. Pengujian juga akan dilaksankan pada berbagai model komputer untuk mencoba apakah program akan berjalan dengan baik atau tidak.

\section{Hasil dan Pembahasan}

\subsection{Deskripsi Program}

Perangkat lunak (software) ini dinamakan @AprediCt yaitu software untuk memprediksi penurunan kadar Asam Askorbat pada buah Jambu Biji. Perangkat lunak simulasi ini nantinya dapat digunakan untuk menentukan kadar penurunan vitamin $\mathrm{C}$ berdasarkan faktor-faktor yang dapat menurunkan kandungan Asam Askorbat pada buah Jambu Biji seperti lama penyimpanan, suhu tempat serta kemasan yang digunakan agar kadar vitamin $\mathrm{C}$ di dalam buah Jambu Biji dapat diketahui penurunannya. Sebagai contoh, kita dapat memprediksi berapa persen penurunan kadar vitamin $\mathrm{C}$ pada buah Jambu Biji ketika disimpan selama satu bulan sehingga dapat mengetahui penurunan mutu buah Jambu Biji. Seperti yang diketahui, vitamin $C$ berpengaruh pada kualitas suatu bahan pertanian. Lama penyimpanan harus diketahui secara pasti agar vitamin $\mathrm{C}$ di dalamnya tidak hilang terlalu banyak sehingga dapat mencukupi kebutuhan vitamin konsumennya.

Nilai simulasi pada perangkat lunak ini didasarkan pada teori kinetika reaksi bahan pangan yang meliputi: teori water activity, orde reaksi, lingkungan dan teori Arrhenius. Software disediakan dalam bentuk executable file (*.exe) yang dapat dijalankan secara langsung atau diinstal pada komputer dengan basis sistem operasi (OS) Windows XP sampai dengan Windows 7. Pada program ini terdapat tiga form yang melengkapi aplikasi, yaitu form 1 untuk menu utama, form 2 untuk Simulasi dan form 3 untuk informasi aplikasi. Gambar masing-masing form dapat dilihat secara berurutan.pada Gambar 1, Gambar 2 dan Gambar 3. 


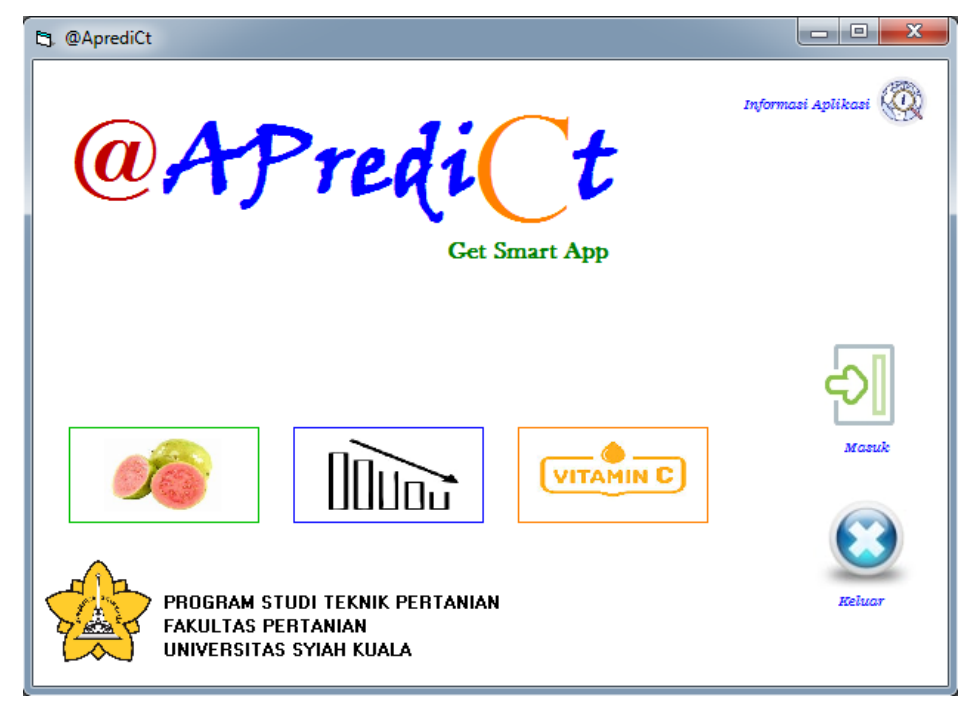

Gambar 2. Tampilan interface form menu utama pada Software @ AprediCt

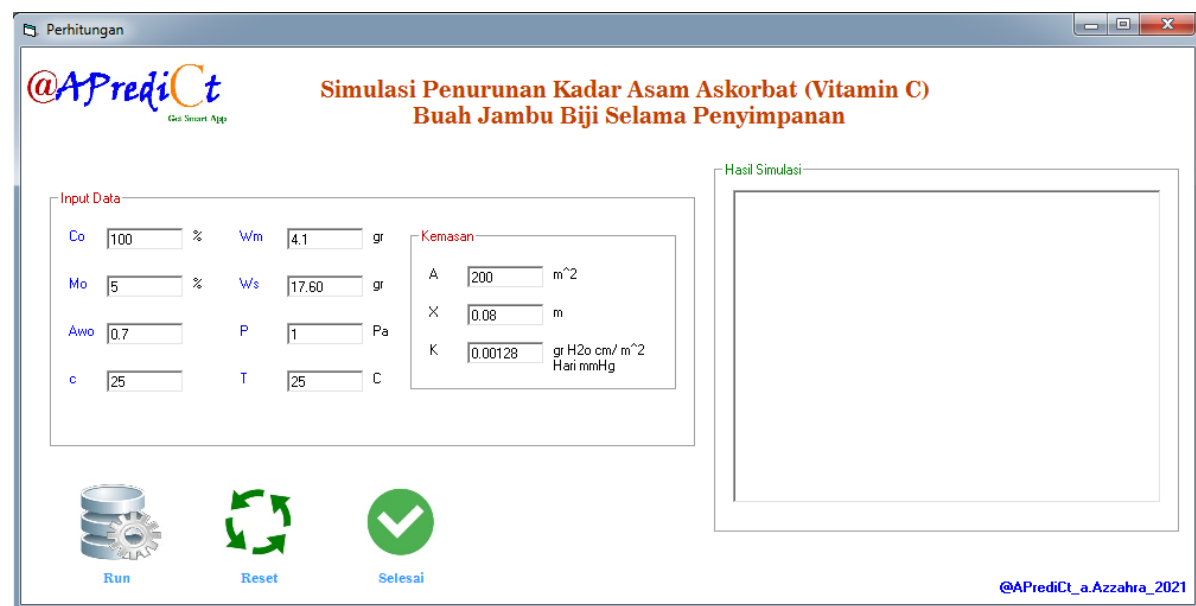

Gambar 3. Tampilan form menu simulasi pada Software @ AprediCt

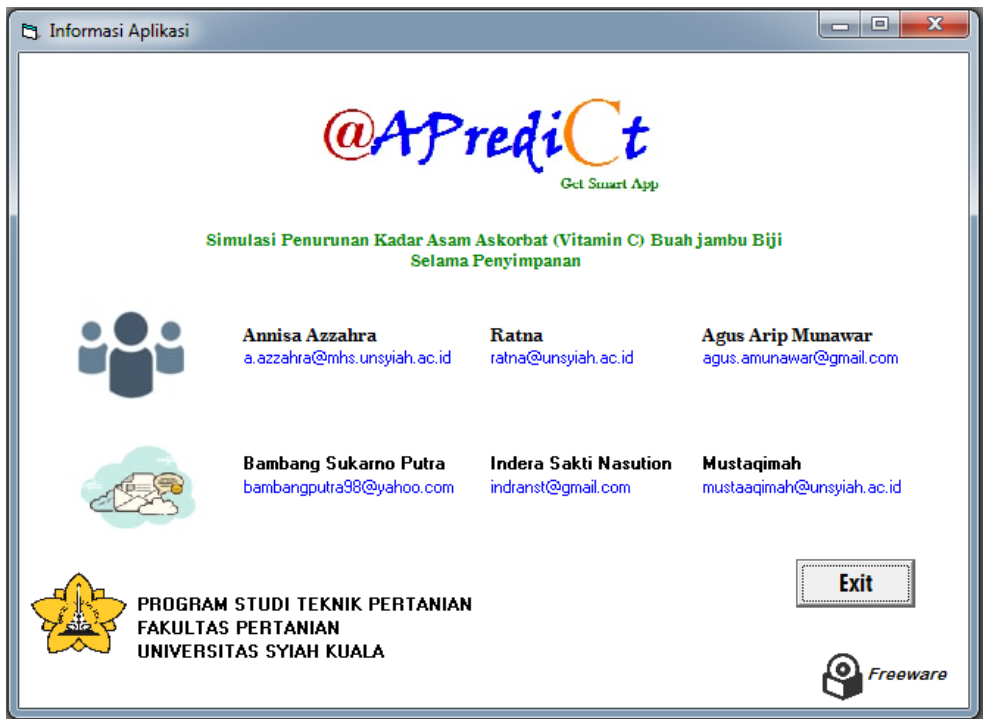

Gambar 4. Form informasi aplikasi

\subsection{Instalasi Perangkat Lunak}

Perangkat lunak@AprediCt tersedia dalam bentuk executable file (.exe) yang dapat langsung dijalankan dan juga tersedia dalam bentuk setup installation package. Setelah tersedia di komputer C:/Program Files/@AprediCt.exe, selanjutnya program dapat langsung dijalankan dengan double click pada icon shortcut seperti terlihat pada gambar berikut ini. 


\subsection{Memulai Aplikasi}

Perangkat Lunak @ Apredict dibangun untuk simulasi penurunan kadar Asam Askorbat pada buah Jambu Biji. Tujuan dari perangkat lunak ini adalah untuk memprediksikan penurunan kadar vitamin C buah Jambu Biji selama masa penyimpanan guna untuk mengetahui sampai kapan batas waktu vitamin C buah Jambu Biji masih terjaga kandungannya. Setelah input data dimasukkan dan simulasi dijalankan, maka kita akan melihat program seperti Gambar 5.

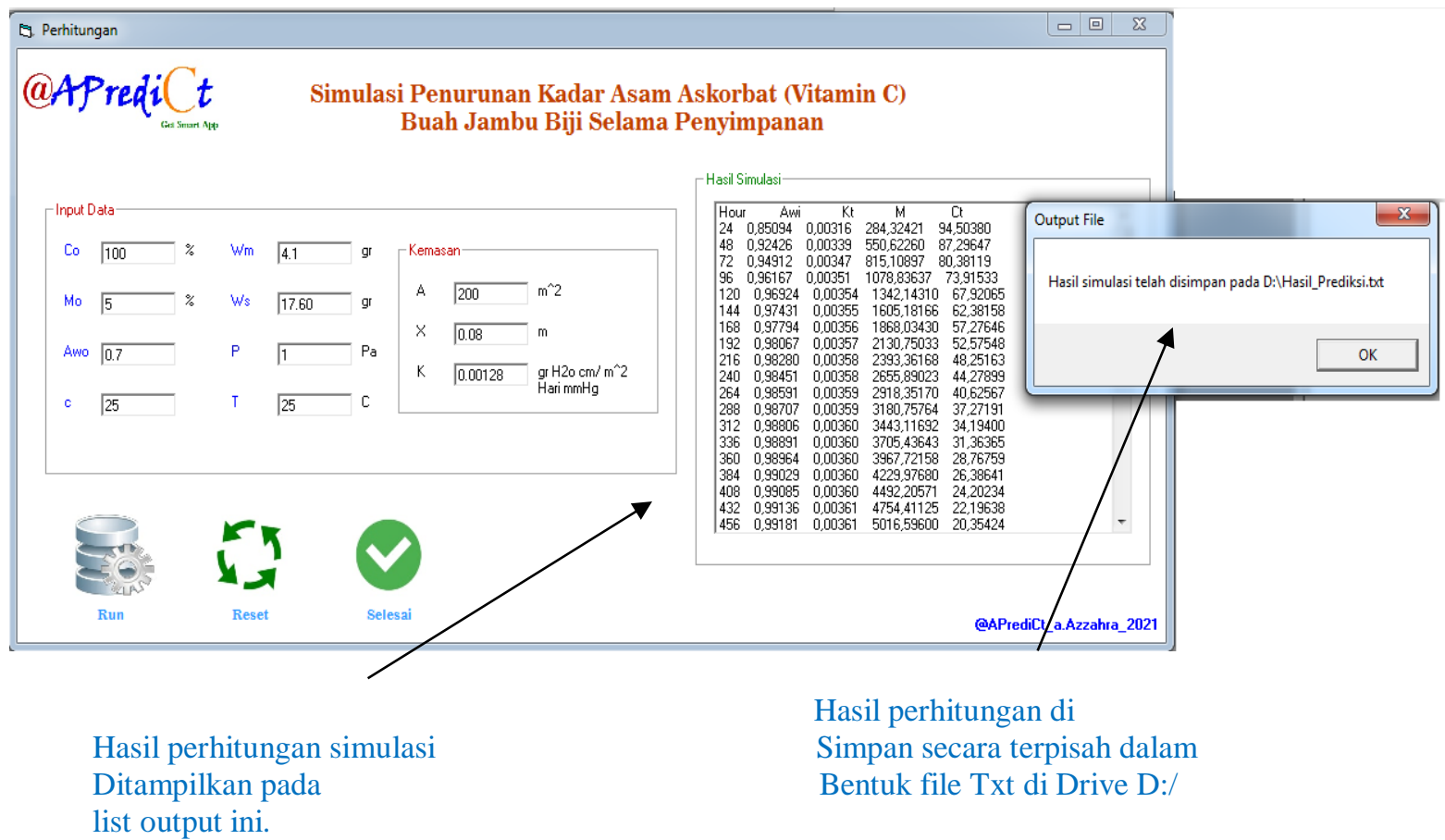

Gambar 5. Gambaran program setelah dijalankan

Data output hasil dari simulasi akan ditampilkan pada list hasil simulasi yang terdapat di sebelah kanan kolom input data. Data hasil simulasi ditampilkan dalam bentuk list. Data output ini nantinya akan tersimpan di drive D dalam format TXT dapat dibuka dengan aplikasi notepad untuk selanjutnya diexport ke aplikasi lain seperti MS Excel.

\subsection{Pengujian Program}

Suatu pemodelan yang dibuat, model tersebut harus divalidasi sebelum digunakan [3]. Model dengan menggunakan bahasa pemograman harus memliki suatu pengujian program (validasi) untuk mengetahui apakah aplikasi yang dibuat dapat berjalan dengan baik atau tidak. Aplikasi @ AprediCt ini dapat memprediksi penurunan kadar Asam Askorbat sampai dengan dengan 30 hari (720 jam) atau selama 1 bulan penyimpanan.

Kandungan Asam Askorbat (vitamin C) pada setiap buah Jambu Biji adalah 183,5 mg/ 100 gr buah jambu biji [8]. Dalam simulasi pada program ini, jumlah kadar Asam Askorbat awal diasumsikan menjadi 100\%. Data input yang diperlukan untuk aplikasi ini adalah faktor dan karakteristik buah Jambu Biji terolah minimal, ukuran dan dimensi kemasan serta faktor lingkungan luar. Data yang akan di input untuk pengujian program ini berasal dari beberapa jurnal yang berkaitan dengan penurunan kadar vitamin $\mathrm{C}$ pada buah jambu biji. Data-data input kandungan buah jambu biji dapat dilihat pada Tabel 1 dan data input kemasan dapat dilihat pada Tabel 2. 
Tabel 1. Data input kandungan buah Jambu Biji

\begin{tabular}{lcc}
\hline Data Input Kandungan Buah Jambu Biji & Jumlah & Peneliti \\
\hline Konsenterasi Kandungan Awal Asam Akorbat (co) & $100 \%$ & {$[2]$} \\
Kadar Air Awal (Mo) & $72 \%$ & {$[12]$} \\
Aktivitas Air Awal (Awo) & 0,75 & {$[12]$} \\
Energi Aktivasi (c) & 3,4 & Suhu Ruang \\
Suhu (C) & $25^{\circ} \mathrm{C}$ & {$[7]$} \\
Berat Bahan (wm) & $275 \mathrm{~g}$ & {$[10]$} \\
Berat Bahan Padatan (ws) & $23,33 \mathrm{~g}$ & \\
\hline
\end{tabular}

Tabel 2. Data input kemasan buah Jambu Biji

\begin{tabular}{lcc}
\hline Data Input Kemasan (Polyethilene) & Jumlah & Peneliti \\
\hline Luas Permukaan Bahan Kemasan (A) & $0,00570 \mathrm{~m}^{2}$ & {$[7]$} \\
Tebal Kemasan (x) & $0,0002 \mathrm{~m}$ & {$[7]$} \\
Koefisien Permeabilitas Bahan Kemasan (K) & 0,00128 & {$[5]$} \\
\hline
\end{tabular}

Data input pada pengujian program ini menggunakan data yang didapat dari jurnal-jurnal yang bersangkutan. Namun, untuk mempermudah penggunaan dalam hal lain (sebagai tujuan pembelajaran), juga dapat digunakan data yang dimodifikasi/dimanipulasi sesuai dengan tujuan pembelajaran.

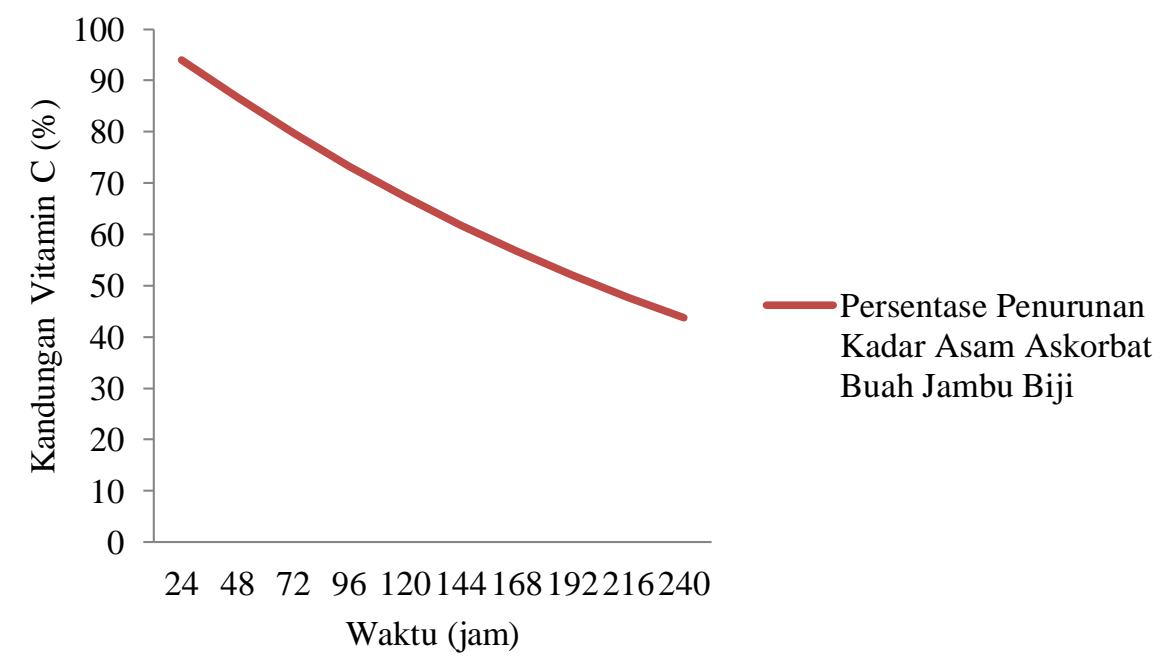

Gambar 6. Persentase penurunan kadar Asam Askorbat buah Jambu Biji menggunakan program simulasi Visual Basic selama 240 Jam

Gambar 6 menunjukkan bahwa dalam 240 jam (10) hari penyimpanan pada suhu kamar $\left(25^{\circ} \mathrm{C}\right)$ kadar Asam Askorbat buah Jambu Biji mengalami penurunan sebesar 56,1\%. Hal ini sejalan dengan penelitian [6] yang pada penyimpanan 10 hari pada suhu kamar $\left(28^{\circ} \mathrm{C}\right)$, kadar vitamin $\mathrm{C}$ mengalami penurunan hampir 50\% dan [4] yang melakukan penelitian secara manual di lapangan yaitu kadar Asam Askorbat mengalami penurunan sebanyak $89,84 \%$ pada suhu kamar $\left(30^{\circ} \mathrm{C}\right)$ selama 10 hari penyimpanan. Jadi simulasi penurunan kadar Asam Askorbat menggunakan Visual Basic 6.0 ini berhasil mendekati angka real penurunan kadar Asam Askorbat yang diuji di lapangan. 


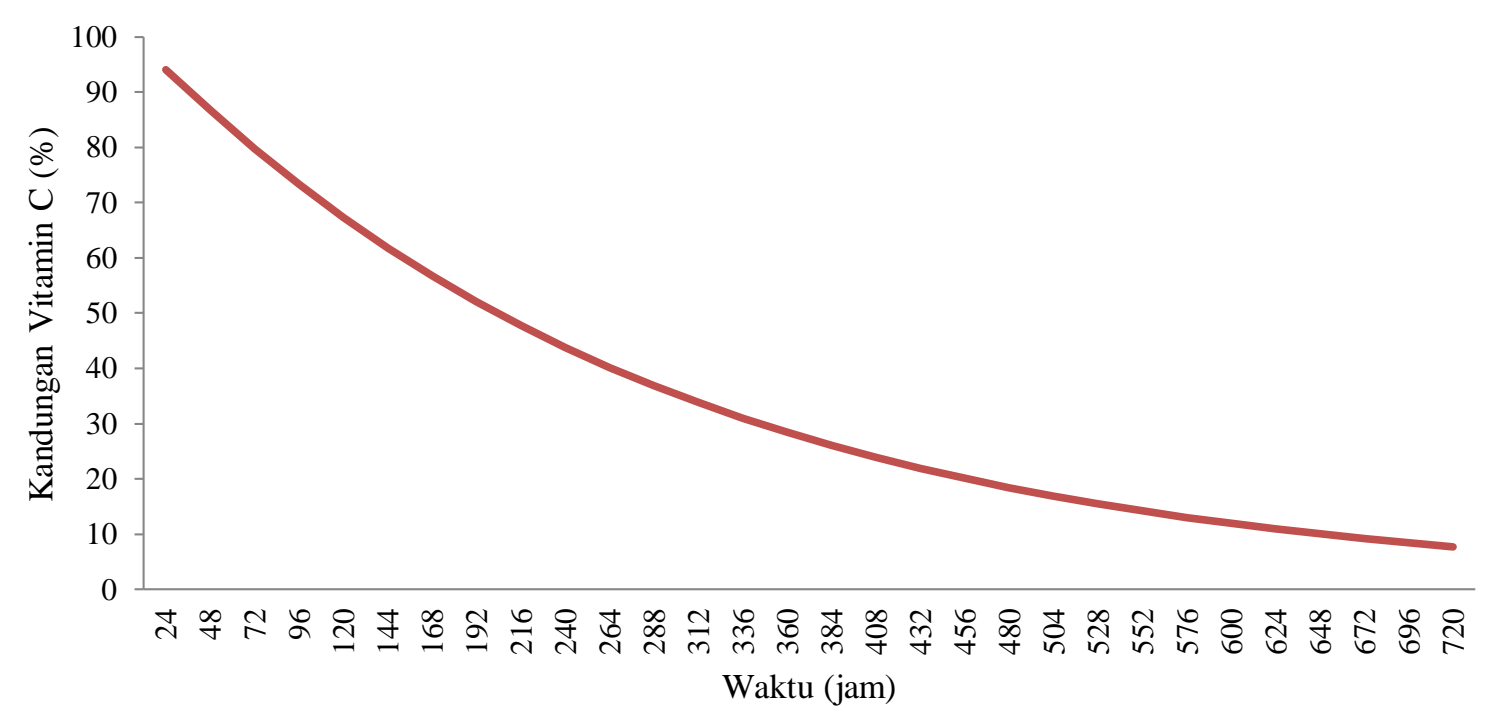

Gambar 7. Persentase penurunan kadar Asam Askorbat Buah Jambu Biji menggunakan program simulasi Visual Basic 6.0 selama 720 jam

Hasil uji program ini juga dapat dilihat pada Gambar 7 yaitu terjadi penurunan kadar Asam Askorbat sebesar 92,26\% yaitu dari 183,5 mg/100 gr menjadi sekitar 12,84 mg/ 100 gr buah Jambu Biji selama 720 jam atau 1 bulan. Penurunan kandungan vitamin $C$ pada komoditi pertanian khususnya buahbuahan terjadi akibat kerusakan vitamin $\mathrm{C}$ yang disebabkan masuknya oksigen dan bertambahnya kadar air selama penyimpanan sehingga terjadinya oksidasi vitamin C [13] dalam [7]. Degradasi Asam Askorbat rentan terhadap kondisi lingkungan seperti suhu dan aktivitas air [15]. [11] menyatakan bahwa pada kondisi suhu kamar, kadar vitamin $\mathrm{C}$ mengalami penurunan yang lebih cepat. Hal ini disebabkan karena pada suhu kamar kondisi lingkungan tidak dapat dikendalikan seperti adanya panas dan oksigen sehingga proses pemasakan buah berjalan dengan sempurna.

\section{Kesimpulan}

Program simulasi penurunan kadar asam askorbat menggunakan Visual Basic 6.0 ini berhasil dibangun dan dapat digunakan untuk memprediksi penurunan kadar asam askorbat buah jambu biji (Psidium guajava). Simulasi penurunan kadar asam askorbat menggunakan Visual Basic 6.0 ini menunjukkan kadar asam askorbat buah Jambu Biji mengalami penurunan sebesar 56,1\% hal ini sejalan dengan penelitian [6] yaitu kadar vitamin C pada buah Jambu Biji mengalami penurunan hampir 50\%. Maka program simulasi ini berhasil mendekati angka real penurunan kadar asam askorbat yang di-uji pada penelitian di lapangan. Hasil simulasi pada program menunjukkan terjadi penurunan kadar asam askorbat sebesar 92,26\%, yaitu menjadi sekitar 12,84 mg/ 100 gr buah jambu biji selama 720 jam atau 1 bulan penyimpanan.

\section{Daftar Pustaka}

[1] Andarwulan, N dan Sutrisno K.1992. Kimia Vitamin. Rajawali. Jakarta.

[2] Arief, D.Z., L.H. Afrianti dan Soemarni. 2018. Karakteristik Fruit Leather Jambu Biji Merah (Psidium Guajava L) dengan Jenis Bahan Pengisi. Pasundan Food Technology Journal. 5 (1): 76-83.

[3] Brown, D.P. 2005. Artificial Intelligence for Creation of Rapid LowCost Models and Simulations. Defense Acquisition University, Technology and Engineering. Department Fort Belvoir. VA 22060.

[4] Dewi, Y.U., Sumantri dan P.L. Utami. 2007. Pengaruh Lama Penyimpanan Terhadap Penurunan Kandungan Buah Jambu Biji (Psidium Guajava Linn). Jurnal Og Pharmacy. 5 (22): 100-105.

[5] Mareta, T.D., dan S.A. Nur. 2011. Pengemasan Produk Sayuran Dengan Bahan Kemasan Plastik Pada Penyimpanan Suhu Ruang Dan Suhu Rendah. Jurnal Ilmu-Ilmu Pertanian UGM. 7 (1) : 26-40.

[6] Masfufatun., Widaningsih., N. Kumala dan T. Rahayuningsih. 2009. Pengaruh Suhu dan Waktu Penyimpanan Terhadap Vitamin C Dalam Jambu Biji (Psidium guajava). Universitas Wijaya Kusuma. Surabaya.

[7] Naibaho, B. 2014. Penggunaan Beberapa Jenis Kemasan Untuk Memperpanjang Masa Simpan Buah Jambu Biji (Psidium guajava L.). Wahana Inovasi. 3 (1): 23-38.

[8] Parimin, S.P. 2005. Jambu Biji. Budidaya Dan Ragam Pemanfaatannya. Penebar Swadaya. Depok. 
[9] Rachmaniar, R., H. Kartamihardja dan Merry. 2016. Pemanfaatan Sari Buah Jambu Biji Merah (Psidium Guajava Linn) Sebagai Antioksidan Dalam Bentuk Granul Effervercent. Indonesian Journal of Pharmaceutical Science and Technology. 5(1): 1- 20.

[10] Raharja, S dan A, Damayanti. 2014. Optimasi Penghambatan Pengendapan Jus Jambu Biji Merah Dengan Metode Sonikasi. E-jurnal Agroindustri Indonesia. 3(1): 172-180.

[11] Tranggono dan Sutardi, 1990. Biokimia. Teknologi Pasca Panen dan Gizi. PAU Pangan dan Gizi Universitas Gajah Mada. Yogyakarta.

[12] Uddin, M.S., M. N. A. Hawlader., L. Ding dan A.S. Mujumdar. 2002. Degradation of Ascorbic Acid in Dried Guava During Storage. Journal Of Food Engineering. 51: 21 - 26.

[13] Winarno, F.G dan S. Fardiaz. 1980. Pengantar Teknologi Pangan. Gramedia. Jakarta.

[14] Christian, R. 2012. Pemodelan dan Simulasi Theophylline Sebagai Sistem Pelepasan. Skripsi. Fakultas Teknik. Universitas Indonesia. Depok.

[15] Singh, R.K. dan D.B. Lund. 1984. Kinetics of Ascorbic Acid Degradation in Storage Intermediate Moisture Apples, In B, M. Mckenna (Ed.). Proccedings of The Third International Congress on Engineering and Food, Vol. 1. Engineering Sciences in The Food Industy. Elsevier. Amsterdam. 